\title{
DIAKRONIKA
}

Vol. 18 No. 2 Th. 2018 p: 100-110

ISSN: 1411-1764 (Print) | 2620-9446 (Online)

http://diakronika.ppj.unp.ac.id

\section{Modul Berbsis Green History Untuk Pembelajaran Sejarah Di Sekolah Menengah Atas}

\author{
Elfa Michellia Karima, Firza \\ elfamichellia.k@fis.unp.ac.id \\ Universitas Negeri Padang
}

\begin{abstract}
The important thing in studying history is to make it more interesting. The teacher as a facilitator must find other ways to make student interested when they learn, so far history learning is less exciting because student are obligated to remember the fact of historical events. Green history-based module learning will provide more interesting learning material for students to understand history since the module integrates paste vents whic hare related to the presentand also witht hesurrounding environment. The purpose of this researc histoimprove students knowledge, skills, and awareness about environmental values andenvironmental issues. This research is development research, which some stages namely Data Collection, Model Design, Design Validation, Design Revision, Product Trial, Product Revision, Mass Production of Products. This research has a positive impact on students in learning history, students understanding increases and students can analyse a historical event.
\end{abstract}

Keywords : Learning History, Green History, Green Hstory Module

\begin{abstract}
Abstrak
Pentingnya mempelajari sejarah membuat guru sebagai fasilitator harus menemukan cara lain agar pembelajaran menarik, selama ini pembelajaran sejarah merupakan pembelajaran yang kurang menarik karena hanya mengingat fakta dari peristiwa sejarah. Pembelajaran dengan menggunakan modul berbasis green history akan memberikan kemudahan bagi peserta didik untuk memahami pembelajaran sejarah karena peristiwa sejarah dikaitkan dengan masa kini dan juga dengan lingkungan sekitar. tujuan dari penelitian ini ialah untuk meningkatkan pengetahuan, keterampilan, dan kesadaran peserta didik mengenai nilai-nilai lingkungan dan isu permasalahan lingkungan. Penelitian ini merupakan penelitian pengembangan, yang juga merupakan penelitian research and development sehingga ada tahapan yang dilalui yaitu pengumpulan data, Desain Model, Validasi Desain, Revisi Desain, Uji Coba Produk, Revisi Produk, Produksi Masal Produk. Hasil dari penelitian ini ialah terdapat dampak yang positif bagi peserta didik dalam pembelajaran sejarah, pemahaman peserta didik meningkat dan peserta didik mampu menganalisis suatu peristiwasejarah.
\end{abstract}

Kata Kunci : Struktural, filsafat spekulatif, pola dasar, konsta 
Elfa Michellia Karima, Firza

Modul Berbsis Green History untuk Pembelajaran Sejarah di Sekolah Menengah Atas

\section{Pendahuluan}

Manusia memiliki ketergantungan terhadap lingkungan di mana ia tinggal karena manusia dan lingkungan merupakan suatu sistem yang saling mempengaruhi. Interaksi yang dilakukan manusia terhadap lingkungan sudah seharusnya merupakan interaksi yang saling menguntungkan yaitu dengan menjaga dan melestarikan lingkungan. Selama ini perilaku manusia identik dengan perilaku penguasa dan pusat dari tatanan alam semesta (antroposentrisme). Hal ini berhubungan dengan diskriminasi yang dilakukan manusia terhadap makhluk hidup lainnya salah satunya dengan eksploitasi alam yang berakibat pada pengrusakan lingkungan. Berbagai permasalahan alam yang disebabkan oleh manusia diantaranya pembakaran hutan, pemanasan global, penipisan ozon, perubahan iklim tak menentu, pencemaran lingkungan, dan lain-lain.

Permasalahan yang terjadi dewasa ini harus segera ditangani agar tidak menjadi suatu permaslaahn yang besar dan merugikan manusia. Kesadaran akan pentingnya menjaga lingkungan serta melestarikannya sudah menjadi tanggung jawab masyarakat dunia seperti yang dinyatakan oleh (Ward \& Dubos, 1972) bahwa bumi hanyalah satu (only one earth) yang kelangsungan hidupnya sangat tergantung kepada manusia untuk menjaga dan melestarikan lingkungan. Dengan pola perilaku yang saling menguntungkan, maka manusia dan alam akan berjalan dengan selaras tanpa merugikan salah satu pihak. Interaksi yang terjadi antara lingkungan dan manusia menciptakan hubungan timbal balik yang dijelaskan oleh (Soemarwoto, 2007) berikut :

"Kelangsungan hidup manusia sangat tergantung pada lingkungan. Manusia terbentuk oleh lingkungan hidupnya dan sebaliknya manusia juga membentuk lingkungan hidupnya. Proses interaksi manusia dengan lingkungannya, sangat mempengaruhi pandangan hidup manusia. Manusia mengamati lingkungan hidupnya dan belajar dari pengalaman interaksi, menyusun citra tentang lingkungan hidupnya, sifat lingkungan hidupnya, pengaruh lingkungan hidup terhadap dirinya, dan reaksi lingkungan hidup terhadap aktivitas hidupnya."

Pentingnya menjaga lingkungan dapat diintegrasikan dengan pembelajaran di sekolah dalam mata pelajaran apapun, salah satunya mata pelajaran sejarah, dengan begitu peserta didik tidak saja memiliki kesadaran akan pelajaran sejarah tapi juga dapat mengimplementasikan pelajaran tersebut dalam kehidupan sehari-hari. Pelajaran sejarah merupakan pembelajaran mengenai peristiwa di masa lalu, nilai-nilai yang terkandung di dalamnya dapat dikaitkan dengan masa kini sebagai bentuk penanaman pengetahuan pada peserta didik. Mempelajari sejarah dapat memberikan pemahaman kepada peserta didik akan pentingnya masa lalu serta sebagai 
bentuk kesadaran baik di masa kini maupun di masa mendatang. Tidak jarang peserta didik merasa bosan dengan pembelajaran sejarah karena biasanya pembelajaran hanya menekankan pada ingatan yang faktual. Siswa dapat memaknai pembelajaran sejarah bila dikaitkan dengan lingkungan hidup sehari-hari sehingga pembelajaran tersebut dapat bermakna. Peserta didik pun akan menjadi aktif dalam pembelajaran karena melalui pembelajaran sejarah peserta didik dilatih untuk dapat mengatasi permasalahan yang ada di sekitarnya dan melestarikan lingkungannya seperti yang jelaskan oleh (Mazza \& Francis, 1995)

"Mewujudkan keseimbangan dan pelestarian lingkungan dalam konsep pembangunan berkelanjutan (sustainable development). Keberlanjutan adalah kapasitas pembaharuan dan evolusi dalam ekosistem, serta inovasi dan kreativitas dalam sistem sosial. Keberlanjutan bukan merupakan akhir yang harus dicapai, tetapi target yang secara terus-menerus dilakukan dalam masyarakat."

Pengembangan pembelajaran sejarah dengan mengaitkannya pada lingkungan hidup merupakan salah satu cara yang dapat digunakan oleh guru untuk mengarahkan peserta didik pada pembelajaran yang bermakna. Siswa yang berada di lingkungan sekolah masih sering dihadapkan pada permasalahan lingkungan yang berkaitan dengan kebersihan. Dengan mempelajari sejarah, maka siswa akan belajar untuk tidak melakukan kesalahan yang sama di masa lalu. Membuang sampah sembarangan di lingkungan sekitar akan mendatangkan bencana banjir. Sebagai solusi dari kerusakan lingkungan maka pembelajaran sejarah dapat menggunakan pendekatan ecopedagogy yaitu pendekatan untuk mengembangkan perilaku hijau. Pengembangan pembelajaran green history merupakan salah satu aplikasi dari pendekatan ecopedagogy yang diwujudkan dalam kecerdasan ekologis dan perilaku hijau. Peristiwa di masa lalu direfleksikan pada masa kini agar dapat dijadikan pembelajaran, hal ini mengajarkan bahwa manusia merupakan bagian dari alam yang hidup berdampingan dengan alam dan saling ketergantungan, pembelajaran tersebut dinamakan dengan Green History. Manusia bukan pusat dari alam seperti yang dijelaskan dalam antroposentrisme, melainkan bagian dari alam karena manusia dapat bertahan hidup hingga kini salah satunya karena alam yang menyediakan berbagai kebutuhan manusia.

\section{Metode}

Jenis penelitian ini ialah penelitian pengembangan atau Research and development (R\&D) yang merupakan sebuah strategi dan metode penelitian yang cakap ampuh untuk memperbaiki praktik (Sukmadinata, 2009). 
Penelitian pengembangan juga diartikan sebagai suatu proses atau Ingkahlangkah untuk mengembangkan suatu produk baru yang telah ada dan dapat dipertanggungjawabkan (Sugiono \& Kuantitatif, 2007) Pada tahap awal telah dilakukan analisis terhadap kurikulum SMA kelas XI Kurikulum 2013, yaitu:

\section{Kompetensi Dasar}

3.1 Menganalisis perubahan, dan keberlanjutan dalam peristiwa sejarah pada masa penjajahan asing hingga proklamasi kemerdekaan Indonesia.

3.2 Menganalisis proses masuk dan Perkembangan penjajahan bangsa Barat ( Portugis, Belanda dan Inggris ) di Indonesia.

3.3 Menganalisis strategi perlawanan bangsa Indonesia terhadap penjajahan bangsa Barat di Indonesia sebelum dan sesudah abad ke-20.

\section{Materi-materi pembelajaran}

\section{Perkembangan Kolonialisme dan} Imperialisme Barat

- Perubahan, dan keberlanjutan dalam peristiwa sejarah pada masa penjajahan asing hingga proklamasi kemerdekaan Indonesia

- Proses masuk dan perkembangan penjajahan Bangsa Barat di Indonesia

- Strategi perlawanan bangsa Indonesia terhadap penjajahan Bangsa Barat di Indonesia sebelum dan sesudah abad ke20.

Tabel 1. Kompetensi Dasar dan Materi pembelajaran Sejarah

Setelah melakukan analisis terhadap materi kelas XI sejarah Indonesia, tahap selanjutnya ialah menentukan peristiwa sejarah yang memiliki kaitan dengan lingkungan.

\section{No. Peristiwa Green History}

1 Revolusi Industri Limbah-limbah industri yang pada saat itu belum disaring secara langsung dapat mencemari air, udara dan lingkungan. Akibatnya, dapat menimbulkan penyakit.

2 Penjelajahan Samudera (Portugis, Spanyol, Belanda Inggris)
- Bangsa Barat melakukan pelayaran pada saat itu menggunakan Kapal yang menggunakan tenaga Uap. Dimana uap dari kapal tersebut banyak mengeluarkan asap yang dapat mencemari udara.

- Penggunaan senjata tembakan, pelurunya menyisakan lapisan yang mengandung bahan plastic yang tidak dapat di urai, sehingga pada saat 
3 VOC

4 Sistem Tanam Paksa

$5 \quad$ Politik Etis

6 Perlawanan Bangsa Indonesia tethadap Penjajahan Bangsa Eropa

$7 \quad$ Politik Ekonomi VOC di tembaknya lapisan tersebut jatuh ke laut dan menyebabkan pencemaran pada air laut.

- Sisa sampah dapur yang mereka gunakan dibuang begitu saja ke laut. Hal ini juga dapat merusak eksosistem yang ada di laut

Diberlakukan sebuah kebijakan yang di kenal dengan nama "ekstirpasi", hal tersebut banyak menimbulkan kerusakan terhadap lingkungan, diantaranya pada saat penebangan, tentunya tanaman akan di bakar dan asap dari pembakaran tersebut menyebabkan polusi udara.

- Tanah Menjadi Lebih Subur

- Mengenal Bibit Unggul

- Padi Gagal Panen

Irigasi Tanah Pertanian

Banyaknya terjadi perlawanan secara gerilya, dalam upaya tersebut mereka melakukan pengeboman, sehingga banyak menyebabkan kerusakan dan juga pencemaran lingkungan. Hutan-hutan banyak yang terbakar dan menjadi rusak. Kemudian karena pembakaran tersebut, asap karena pembakaran menyebabkan pencemaran lingkungan dan udara menjadi tidak sehat

Penebangan Pohon Rempah-Rempah

Tabel 2. Peristiwa sejarah dan kaitannya dengan green history

Pendasainan modul yang dilakukan hingga menjadi modul yang utuh dan memiliki konten menarik ialah melalui proses analisis materi, mengaitkan peristiwa sejarah dengan lingkungan, serta menambahkan gambar yang mendukung penjelasan tersebut.

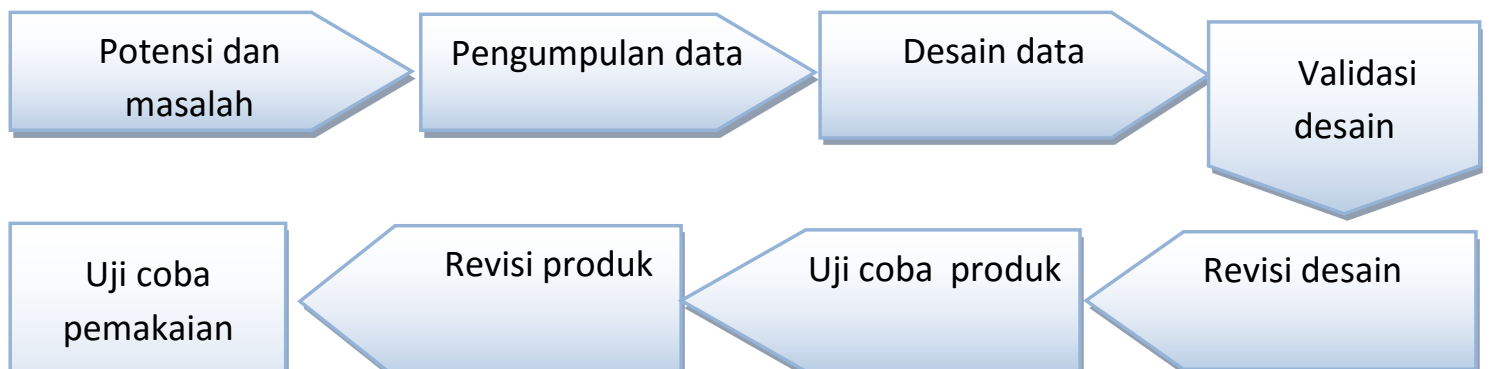


Penelitian yang bersifat analisis dapat menghasilkan produk tertentu digunakan untuk kebutuhan dan untuk menguji keefektifan produk agar berfungsi di masyarakat luas. (1) potensi dan masalah, (2) pengumpulan data, (3) desain Produk, (4) Validasi Desain, (5) Revisi Desain, (6) Uji coba Produk, (7) revisi Produk, (8) Uji Pemakain, (9) revisi produk dan (10) produksi masal.

\section{Hasil dan Pembahasan}

Pembelajaran sejarah dengan pendekatan ekopedagogi memberikan kesempatan pada peserta didik dalam mengembangkan pemahamannya. Tidak saja hanya mempelajari mengenai fakta-fakta sejarah tetapi juga dapat mengambil nilai-nilai yang terkandung di dalamnya, dengan begitu siswa memiliki karakter dan keterampilan yang baik terhadap lingkungan sekitar. Pembelajaran yang juga mempelajari nilai-nilai yang terkandung di dalamnya akan memberikan suatu pembelajaran yang bermakna dan membantu siswa dalam memaknai hubungan manusia dengan lingkungan.

(Liu, Hollingshead, Swiatlo, Lawrence, \& Austin, 2005) mengatakan perlunya manusia untuk menjaga lingkungan tempat tinggal agar dapat hidup berkelanjutan.

"Ecopedagogy menunjukkan bahwa makna hidup kita sama sekali tidak lepas dari makna planet itu sendiri, dan bahwa untuk mencapai pembangunan berkelanjutan, kita harus menumbuhkan gaya hidup berkelanjutan yang menghubungkan kita ke alam semesta yang lebih besar hidup”.

Kecerdasan ekologis yang dimiliki oleh peserta didik dapat diterapkan dalam aktivitas sehari-hari terhadap suatu ekosistem manusia yang berdampak 
dalam mengurangi kerusakan dan melestarikan lingkungan hidup. Pembelajaran yang berbasis ecopedagogy ini dapat dijadikan upaya dalam mengubah perilaku maupun sikap peserta didik yang berkaitan dengan lingkungan hidupnya. Lingkungan hidup merupakan hal yang penting untuk dijaga karena merupakan tempat tinggal manusia serta dapat memberikan peningkatan kualitas hidup seseorang termasuk peserta didik. Tujuan dari pembelajaran ini yaitu untuk meningkatkan pengetahuan, keterampilan, dan kesadaran siswa tentang nilai-nilai lingkungan dan isu permasalahan lingkungan. Peserta didik pun akan berperan aktif dalam upaya pelestarian dan keselamatan lingkungan untuk kepentingan generasi sekarang dan yang akan datang.

Pembelajaran sejarah tidak hanya mengkaji mengenai masa lalu tetapi juga mengenai perilaku manusia. Tidak jarang perilaku orang terdahulu memberikan dampak positif pada orang banyak pada masa itu atau masa sekarang. Hal ini dapat dimanfaatkan dalam pembelajaran sejarah dengan pendekatan ecopedagogy agar peserta didik dapat meniru nilai-nilai yang telah diberikan oleh orang terdahulu untuk diterapkan pada masa kini. Pembelajaran sejarah yang dikaitkan dengan lingkungan dan penghijauan disebut dengan green history. Sebagai implementasi green history, peserta didik mempelajari tentang Raja Purnawarman dari Kerajaan Tarumanegara yang membuat saluran air Gomati yang terdapat dalam Prasasti Tugu sebagai pencegahan banjir. Siswa yang mempelajari green history akan menyadari akan pentingnya menjaga lingkungan. Tindakan positif yang dilakukan oleh orang di masa lalu memberikan dampak positif pada lingkungan. Mengembangkan green history akan meningkatkan perilaku hijau atau green behavior peserta didik. Hal ini merupakan pendekatan dari ecopedagogy dalam mengembangkan suatu perilaku yang bermanfaat bagi lingkungan sekitar.

Memasukkan permasalahan-permasalahan kontemporer sangat penting dalam pembelajaran sejarah. Permasalahan kontemporer tersebut berangkat dari permasalahan yang dialami oleh peserta didik. Seperti yang dikemukakan oleh (Supriatna, 2007)

"Menempatkan masalah-masalah aktual dalam pembelajaran sejarah dengan menariknya dari topik pembelajaran dalam kurun waktu sejarah yang dipelajarinya tidak hanya menjadikan pembelajaran sejarah lebih bermakna (meaningful) dalam kehidupan sehari-hari siswa melainkan juga sekaligus menjadikan mereka sebagai pelaku sejarah.” 
Modul yang disusun merupakan modul pembelajaran sejarah, pada penyajiannya modul ini dilengkapi dengan cover yang menarik bagi peserta didik dan mencirikan tujuan dari pembuatan modul ialah selain membahas materi sejarah juga menonjolkan aspek lingkungan. Selanjutnya modul juga dilengkapi dengan kata pengantar dan daftar isi sebagai sarana memudahkan peserta didik mencari halaman materi yang dituju. Bagian yang membedakan modul dengan buku paket lainnya ialah terdapat petunjuk penggunaan modul. Fungsi dari petunjuk penggunaan modul ini ialah agar peserta didik memahami mengenai apa saja yang harus dilakukan dan apa saja yang terdapat modul pembelajaran tersebut. Memasuki materi pembelajaran dalam modul diawali dengan Bab Pendahuluan di mana peserta didik dapat membaca ringkasan dari isi modul tersebut, pendahuluan memiliki rincian latar belakang, deskripsi singkat, tujuan serta materi pokok dan sub materi pokok dalam buku tersebut. Pada bab ini materi sejarah mengenai mulai masuknya bangsa Barat ke Indonesia. Hal ini disebabkan salah satunya oleh Revolusi Industri yang terjadi di Inggris dan bangsa Barat yang memiliki paham merkantilisme. Maka dengan ambisi bangsa Barat untuk mengumpulkan emas dan bahan mentah lainnya mulailah berlayar mencari ke dunia Timur, dan sampilah ke Indonesia. Akibat yang ditimbulkan oleh Revolusi Industri ini ialah pencemaran lingkungan baik yang terjadi di udara akibat banyaknya asap pabrik-pabrik dan juga tercemarnya air yang berasal dari limbah. Modul ini memaparkan akibat dari peristiwa sejarah tersebut yang di fokuskan dalam sebuah kotak khusus. Modul juga dilengkapi dengan gambar visual yang memudahkan peserta didik memiliki gambaran mengenai peristiwa masa lalu tersebut. Inilah salah satu fungsi dari user-friendly sebuah modul. Selain mendesain modul, beberapa revisi juga dilakukan untuk memperbaiki modul. Dari hasil validasi yang dinyatakan oleh validator ada beberapa hal yang menjadi aspek penting perbaikan modul ini.

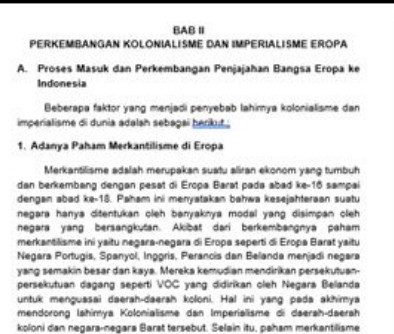




\section{Gambar 1. contoh modul berbasis green history} Sumber : Internet 2018

Pembelajaran yang bermakna mengenai green history diwujudkan dalam bentuk perbuatan yang dapat memberikan dampak positif pada peserta didik karena pengetahuan akan dibangun secara aktif oleh peserta didik melalui persepsi dan pengalaman langsung dengan lingkungannya. Kehidupan peserta didik yang banyak bersentuhan dengan alam maka akan dengan mudah memaknai pembalajaran tersebut. Untuk menciptakan suasana pembelajaran seperti itu maka peserta didik harus diberikan kesempatan untuk berinteraksi dengan lingkungannya secara aktif. Pendekatan ini masih jarang digunakan karena tidak sedikit guru yang hanya menekankan pada aspek kongitif saja pada pembelajaran sejarah sehingga peserta didik tidak menemukan suatu hubungan antara yang dipelajari dan kehidupan yang dihadapinya. Pembelajaran yang hanya menekankan pada sisi kognitif saja tidak akan memberikan makna bahkan peserta didik cenderung akan cepat lupa. Peserta didik juga akan mulai berpikir secara objektif terhadap suatu peristiwa sejarah, peserta didik mulai menemukan faktor pendukung lain dari terjadinya suatu peristiwa sejarah karena ada dukungan dari ilmu bantu lainnya (Karima, 2016)

Siswa perlu mendukung gerakan ini karena merupakan salah satu dari green behavior. Green history yang dapat dikembangkan yaitu pembelajaran masa kolonial ketika VOC melakukan kebijakan ekstirpasi atau penebangan cengkeh untuk menjaga harga rempah-rempah tidak turun selain itu setelah VOC bangkrut diterapkan Cultuurstelsel oleh van den Bosch. Terjadi pergeseran fungsi hutan heterogen menjadi lahan perkebunan teh, kopi, cengkeh, kina dan lain-lain sebagai komoditas pasar global. Eksploitasi ini menyebabkan berkurangnyanya ketersediaan sumber daya alam. Perubahan hutan heterogen menjadi lahan homogen menjadikan lingkungan tercemari di tambah banyaknya perusahaan asing yang didirikan. Tidak saja eksploitasi 
Elfa Michellia Karima, Firza

Modul Berbsis Green History untuk Pembelajaran Sejarah di Sekolah Menengah Atas

tanaman tapi juga eksploitasi tenaga manusia. Peserta didik akan termotivasi untuk tidak melakukan hal yang sama melalui pembelajaran dengan menggunakan pendekatan ecopedagogy. Mereka akan mendukung gerakan walikota dalam menghijaukan Bandung dengan berbagai macam tumbuhan dan ikut serta dalam menjaganya. Siswa juga akan memahami pentingnya fungsi taman kota dan tidak merusak tumbuh-tumbuhan yang ada dilingkungan sekitarnya. Kecerdasan ekologis juga dapat diimplementasikan dalam kegiatan lainnya seperti mematikan lampu, menghemat air, bersepeda untuk bepergian atau menggunakan produk yang dapat digunakan berulang.

Peningkatan kompetensi ekologis peserta didik harus ditingkatkan baik dalam aspek kognitif, sikap, keterampilan, dan partisipasi agar memiliki kesadaran, sikap serta perilaku untuk menyadari adanya hubungan timbal balik antara manusia dan lingkungannya. Pembelajaran di kelas serta sekolah merupakan tempat yang strategis dalam mengembangkan karakter peserta didik serta penanaman nilai-nilai moral terhadap kecintannya terhadap lingkungan hidup. Ekologis ini biasanya hanya dipahami peserta didik sebagian saja tidak mendalam yang terlihat pada perilaku hijau sehari-hari peserta didik. Sehingga, kesadaran dan kepedulian terhadap lingkungan hidup belum tertanam kuat dan belum dapat menyelesaikan permasalahan lingkungan. Selanjutnya, diharapkan siswa memiliki pemahaman yang komprehensif dalam berinteraksi dengan lingkungan dengan mengubah etika antroposentrisme yang memandang alam diciptakan untuk manusia sebagai sumberdaya yang dieksploitasi secara optimal (Soemarwoto, 2001).

\section{Kesimpulan}

Melalui pembelajaran green history maka siswa akan mengenal permasalahan yang timbul akibat ketidakpedulian terhadap lingkungan selain itu melalui green history akan menimbulkan kecerdasan ekologis yaitu kesadaran siswa terhadap pengembangan ramah dan peduli lingkungan serta dapat mengurangi dampak buruk tersebut dengan perilaku hijau. Perilaku hijau selain diterapkan dalam pembelajaran juga harus didukung oleh sekolah untuk menjaga lingkungan.

\section{Daftar Pustaka}

Karima, E. M. (2016). Pengaruh Metode Pembelajaran Terhadap Berpikir 
Historis Peserta Didik Dalam Pembelajaran Sejarah. Universitas Pendidikan Indonesia.

Liu, D., Hollingshead, S., Swiatlo, E., Lawrence, M. L., \& Austin, F. W. (2005). Rapid identification of Streptococcus pyogenes with PCR primers from a putative transcriptional regulator gene. Research in Microbiology, 156(4), 564-567.

Mazza, G., \& Francis, F. J. (1995). Anthocyanins in grapes and grape products. Critical Reviews in Food Science \& Nutrition, 35(4), 341-371.

Soemarwoto, O. (2001). Atur-diri-sendiri: paradigma baru pengelolaan lingkungan hidup: pembangunan ramah lingkungan: berpihak pada rakyat, ekonomis, berkelanjutan. Gadjah Mada University Press.

Soemarwoto, O. (2007). Atur-diri-sendiri: paradigma baru pengelolaan lingkungan hidup: pembangunan ramah lingkungan: berpihak pada rakyat, ekonomis, berkelanjutan. Gadjah Mada University Press.

Sugiono, M. P. K., \& Kuantitatif, P. (2007). kualitatif dan R\&D. Bandung: Alfabeta.

Sukmadinata, S. (2009). Nana, Metode Penelitian Pendidikan, Bandung: PT. Remaja Rosdakarya.

Supriatna, N. (2007). Konstruksi Pembelajaran Sejarah Kritis. Historia Utama Press, Jurusan Pendidikan Sejarah FPIPS, UPI.

Ward, B., \& Dubos, R. (1972). Only one earth. The care and maintenance of a small planet. Harmondsworth: Penguin Books Ltd. 